\title{
Bataille on Immanent and Transcendent Violence
}

\section{Zeynep Direk}

Violence is perhaps one of the most difficult concepts in Georges Bataille's thought. This essay aims at discussing it by concentrating on Bataille's Theory of Religion. ${ }^{1}$ I shall argue that, in order to understand what Bataille means by "violence," we should distinguish between "immanent violence" and "transcendent violence," and that this distinction is implicit in his thought. Such a distinction is helpful in clarifying several ontological issues. It enables us to distinguish the violence in nature from the violence in the profane world and to put into question the naive view that all violence is a return to animality or the return of animality to inter-human relations. To conceive human violence in terms of animality attests to the metaphysical opposition between man and animal in which "man" stands as the higher term, which affirms the superiority of the human species over all the other animal species. Thus a return to animality would be represented as a regression, which is necessarily negative. For Bataille, on the other hand, it seems that being in touch with our own animality may be an important way to experience immanence and a powerful resource for a critique of Western civilization. 
What I call "transcendent violence" is not a return to animality, nor is it a "sovereign experience" in Bataille's sense. It gives rise to the regimes of servitude in which the subject loses itself in the power relations that belong to systems of production and restricted regimes of consumption and serves to establish the hierarchical differences among individual human beings. "Sovereignty" is misread when it is taken to mean an affirmation of the violence that gives a human being a feeling of superiority or transcendence over others. Bataille conceives of "sovereignty" in terms of "immanent violence." An inquiry into the phenomenon of sacrifice is only one way of approaching immanent violence, for laughter and erotic experience are other experiences in which immanent violence manifests itself. The key to that kind of violence can be found in Bataille's statement that "intimacy is violence" (TR 312/ 51). Bataille locates intimacy in the realm of immanence, which I take to be the impersonal, incarnated ground of our existence in which we are always already interconnected with other living beings.

In the archaic world of paganism, immanence acquires a sacred and divine character as soon as the profane world of work and action begins to separate itself from the intimacy of all beings. In describing that moment, Bataille qualifies immanence explictly as "continuous," "impersonal" and "without distinction," and qualifies intimacy as "profound subjectivity" (TR 301/33). In The Accursed Share, he interprets that ground in terms of the dynamic and fluid life energy that is always in excess. Life is always already excessive because every living organism receives more energy from the cosmos than the amount sufficient for its self-preservation. In contrast to the limited problems of classical economy, "in the general problem there always reappears the essence of the biomass, which must constantly destroy (consume) a surplus of energy."2

Immanence can never be articulated in terms of the opposition between subject and object, which characterizes experience in the profane world of work, action and project. 


\section{BATAILLE ON VIOLENCE}

However, it is the place of a deep subjectivity, a confused, non-reflective consciousness of the self that is not limited by the I or other I's (TR 300/31). I believe that Bataille is a radical thinker of subjectivity, and his attempt to go beyond the classical notion of the subject can be related to Merleau-Ponty's thinking of subjectivity as incarnated in The Phenomenology of Perception. What Merleau Ponty calls "the ante-predicative life of consciousness" or "the silence of primary consciousness" is the natural perceptive involvement of incarnated existence with the world. ${ }^{4}$ In that involvement, the relation with the other is not based on absolute separation, but on the fact that bodily operative intentions read, understand, constantly connect, and affectively communicate with each other. Merleau-Ponty writes that operative intentionality "produces the natural and ante-predicative unity of the world and of our life"; it furnishes "the text which our knowledge tries to translate into precise language." For both Merleau-Ponty and Bataille, subjectivity as the immanent unity of the world and life can never become the object of knowledge, although it can be "experienced." Such an experience, which implies the loss of a subject as clear consciousness of objects is, in Bataille's economical terms, nothing but an unlimited expenditure of energy. Bataille thinks that the subject, as an individual and separate being, belongs to transcendence, for it has always already transcended the natural environment and is in a position to know objects from the outside. Knowledge is a possibility of transcendence, going outside of oneself to an impenetrable other. Moreover, that transcendence is related to violence not only because representation is violent but also because the subject in the world of work is subordinated and servile. The violence to which animals are exposed in nature is very different than the violence to which we are exposed, and which reproduces us in the world of work as knowing, acting, speaking subjects.

In the technological era, man lives under the domination of anonymous powers and experiences. He is subject to both oppression and the empty promises of 
transcendence. According to Bataille, the deep truth of subjectivity is never revealed by transcendence. Although he believes that the expenditure of the forces of the body-for example, erotic experience and laughter--may open a way for the realm of immanence in which we re-establish our continuity with all living and non-living beings, this feeling of continuity is for him nothing more than a brief touching of the untouchable. The fact that he talks about "the lost intimacy" in our being even in the context of his historical discourse on the displacement of the borders between the sacred and the profane in successive historical worlds may give rise to the impression that Bataille is giving expression to a desire to go back to our archaic, immediate animal existence by transgressing our subjectivist and objectivist modern cultures. That way of reading Bataille can make his thought look like some sort of metaphysical nostalgia. However, this interpretation becomes suspect if we emphasize that the loss here is not the absence of something that was previously present, but the absence of something that is still present in our lived experience-even though it is erased, forgotten, and constantly ignored by the ways in which we schematize our experience. Our lost intimacy with other living beings-from which immanent violence is never missing-is animal as well as divine, life as much as death. Perhaps we need to treat "immanent violence" as an ontological concept that may call for interpretation on the basis of an ontology of life. Obviously, this constitutes the ontological foundation of Bataille's further distinction between interior and exterior violence, in terms of which he reads destruction in societies. The distinction between immanent and transcendent violence I find in Bataille has an explanatory value as an analytical tool. At the final analysis, it will be especially useful in understanding why Bataille refrains from condemning violence in purely ethical or political terms. 


\section{BATAILLE ON VIOLENCE}

How does Bataille draw the species barrier between non-human animals and human animals? He believes, with Nietzsche, that the world of things, individuals, work, utility and action transcends immanent life. In a sense, only when we were not yet "human" were we completely immanent to nature. In Theory of Religion, he conceives of non-human animality in terms of "immanence" and "immediacy" (TR 291/17). The emphasis on "immediacy" marks a life limited to the realm of the sensible. A non-human animal is deprived of universal concepts and ideas that serve as schemes for constructing a world out of life. Immanence is determined by an inability to overcome the environment in which a living being spends its life. Transcendence is the overcoming of the sensible toward the concept that frames nature, whereas immanence is being imprisoned in the environing sensible element.

We should note that this use of the couple "transcendence-immanence" singles out man among other species as a builder of the world, failing to emphasize that as humans we inhabit the earth along with other species. The definition of man as a "thinking animal" immediately gives way to a discourse articulating what thinking may mean as a specific difference, and usually not to what we may share with other animal species. But for Bataille, what is left unthought in this definition is precisely our being inside animality as well as outside it. As an animal species on earth, we have ventured outside the immanent continuity of being by a movement of transcendence. Because our intelligence originates in an interruption of immanence, it is bound to remain ignorant of its source. Intellegence can never return to immanence without losing itself in it, and in the realm of transcendence it fails to attain consciousness of the fact that the kernel of our being still belongs to immanence. 


\section{ZEYNEP DIREK}

Nevertheless, Bataille does not merely affirm that we can swim upstream, against intelligence, using intelligence against itself to create an opportunity to find an exit to a conscious experience of the internal relation of all living beings. Only the violence which I exert, or to which I am exposed, can tear apart the constructed structures of the world of subjects and objects in which life is suffocated, and can give us access to sovereign experiences of immanence. Selfconsciousness in Bataille's sense, which is not-knowing, is only possible through such experiences. Intelligence is bound to remain foreign to the life that gave rise to it: it can only enframe, intervene and know nature from the outside; it will always fail to communicate with life from within. However, mental life consists not only of rational thinking. The immanent flow of our incarnated consciousness, which is essentially an internal relation of communication with others in unceasing differentiation, is not constituted or controlled by a knowing subject. By "incarnated existence," we here need to understand impersonal existence, the il ya in which life communicates with itself. We gain access to that immanence and experience it only through the interruption of the world of utility and work, and the dissolution of the individuality that makes possible the overcoming of the separation of beings from each other. In our contact with the elements, in nutrition, in the satisfaction of our needs, in desire and erotic experience, we take part in the rhythm of communication of life with itself, even though cultural forces persuade us to control that contact with animal existence within us to tame it and forget it.

"Immanence" for Bataille does not mean immanence to an object or a subject but to a total Being or "One." An animal's lack of access to transcendence does not imply that it is a being closed in its inner world, for it does not have an inner world in which to enclose itself. Animal is immanent to the environment in which it lives and does not have the capacity to transcend it. But how is this milieu, this "One", described? Bataille depicts it by invoking the type of certainty 


\section{BATAILLE ON VIOLENCE}

that manifests itself "when an animal eats another one" (TR $291 / 17)$. When an animal eats another one, the meaning of the situation in which the former finds itself is clearly similar to that of the latter. The similarity between the meanings of those two situations cannot be found in the sensations that the animals have, for one is being torn to pieces by the other. Nevertheless, both animals are immanent to one and the same medium, which does not make the one who is active in eating "transcendent" with respect to the other who is eaten. In some kinds of animals, during the period of copulation males fight for females and those males who prove to be stronger chase away the others. There is a difference between the victorious animal and the defeated one. However the victory, if it is not by chance, proves nothing else than a quantitative difference of strength (TR 292/18). The establishment of such a difference does not make the victorious male transcend the others. The acts of killing, winning, and copulating give rise to a feeling of "transcendence" only in the human world, due to the "objectification" of the other as passive.

In opposition to the immanent violence in nature, violence is seen as a mark of transcendence in the human world. It bears in itself the promise of elevating man to God, enabling him to incorporate an image of Him. Revealed religions ban homicide and human sacrifice. In the Muslim religion, to take away someone's life, given to him/her by God, is to transgress the limits of the realm in which human beings can legitimately use their power. To kill someone is to usurp God's authority over life and death and thus to set one's self as an equal to God. This is why only wars fought in the name of God can legitimate the killing of human beings. The idea that, in killing, the murderer substitutes himself for God, bears in itself the implicit tendency to think that violence can deify a human being. Physically abusive husbands, parents, torturers and rapists take themselves to be transcending their victims. This sense of transcendence is accompanied by a pleasure stemming from their perception of physical superiority as constituting an ontological, epistemological, and even a moral 
difference. In Theory of Religion, Bataille writes, "The lion is not the king of the animals. In the movement of waters, he is only a higher tide that can reverse the weaker ones. That an animal eats another does not change a fundamental situation: every animal is in the world like water in water" (TR 292/18-19). ${ }^{6}$ By contrast, man is not in the world like water in water. Even a superficial glimpse of "social status" in the human world will show that factors such as "education," "gender," "ethnicity," "race," and "class" intersect to constitute quite incomparable situations.

The power of transcendence in the world of work, utility and action rests on situational differences, and the subject who assumes a status that such crisscrossing of differences may assign to it pays for this by losing his/her own sovereign self. To the genealogy of the transcendence of the subject belong the experiences of fear, submission, guilt, self-contempt, self-hatred, imitation of the desire of the other, and the illusion of self-sufficiency, self-coincidence and independence. Being before the law and entering it, the fundamental experience of the symbolic order is a trauma. In the world of work, in order to become a subject, one needs to sacrifice one's self in the face of power, repress one's immediate desires, reconcile oneself with the authority, accept being rewarded and punished by it and delay free selfexpression until one has nothing left to express. Bataille seeks ways of transgressing the limits of a life of submission to the world of power relations, but he is skeptical about the "warrior of freedom" as well. Both the submissive self and the revolutionary self become subjects by being exposed to transcendent violence, and they are produced by their opposite reactions to it. Oppressive systems of power do change by sacrificing or marginalizing those who fight for freedom, yet their challenge and resistance open the path of communication for those who keep silent out of fear of persecution as surrogate victims. Freedom fighters become surrogate victims. However, it is also true that, even when they cannot make a difference that directly changes the oppressive systems, they 


\section{BATAILLE ON VIOLENCE}

open the way for the discourse that paves the way for transformation. The fighter for freedom may be saving the dignity of the environment, but he/she cannot attain his/her self consciousness in so far as he/she is committed to action and work for the common utility. An interior outlet to immanence is neither possible for those who wait for their turn to be in charge of power nor for the marginalized revolutionary. In short, struggle for power, no matter what the consequences are, takes one away from the direction of the immanence in which Bataille sees "the sovereign good" and the ultimate possibility of our existence. Neither submission to law and authority nor revolt may lead to immanence. Occupying a position of power within a system licenses the subject to use violence. The feeling of transcendence experienced as the possessor of that power is in fact illusory, for the truth is that one is temporarily possessed by that power. Because one is only the surrogate subject, the transient host of power, the truth of the appearance of subjective potency is nothing but impotence. Immanent violence targets this illusory sense of transcendence.

For example, Fight Club, one of the cult movies of recent years, lends itself to being read in terms of the question of the unleashing of immanent violence against the much greater violence embedded in a society organized by advanced capitalist relations of production. ${ }^{8}$ The anti-heros of this movie exert immanent violence to destroy the ways in which life is possessed by the desire to possess. They find relief in a play of violence among friends which makes winning and losing insignificant and yet their immanent violence risks being lost in revolutionary terrorism. Fight Club seems to begin in Bataillean fashion as a "project against the project" and ends up as a struggle to prevent the other's death to which it leads. This struggle is not the result of a conflict between the return to immanence and morality or religion. It is a struggle between transcendent and immanent violence. The argument that a living being's life can be sacrificed for higher ends is a mark 
of transcendent violence, for there are no such ends in immanence. Of course, this is not to say that immanence has no risk or no danger.

A plane of immanence on which no concern for transcendence can have a hold manifests itself with an unthinkable power to emancipate. A globalizing world promises no history that would make mankind even more transcendent. Technology tolerates only the accumulation of information which supplies no critical resources. Given this present state of affairs, violence seems to have already lost the promise of transcendence. However, one may ask about the victims of immanent violence too. For example, what about the pornographic snuff movies which cause the deaths of thousands of women in the world? Would that be a phenomenon of immanent violence?

Let us turn to Theory of Religion before we speculate about how Bataille might answer that question. The violence that makes transcendence possible presupposes an act of objectification. Unlike human consciousness which distinguishes itself from its objects, an eagle that attacks a lamb does not distinguish it from itself. An object is by definition that which is thrown in front of an onlooker, and thus something I can set up over against myself. Unlike the hammer I use or the other whose hand I hold, an object can never be an extension of my living body. The eagle does not perceive the lamb as an object. Animals do not have an "outside world" that consists of objects. Given that objects are temporal syntheses, and presupposing with Bataille that the dimension of future that marks intelligence is not open to animals, an animal cannot see its prey as an object. According to Bataille, the eating of one animal by another is consumption, an extermination that has no duration and occurs in an actual time in which nothing is objectified. ${ }^{9}$ Neither can we say that an animal that eats another one is using it. The eagle is immersed in the nutritive "element" in the act of emptying the intestines of the other that it lays open. In contrast to the relation with an object, the immanent 


\section{BATAILLE ON VIOLENCE}

relation with the other does not involve a separation, a distinction between me and the other. According to Bataille such an internal relation with the other has no duration, that is, it is always in the present. This is not to say that it is closed to the future. However, the future here is not the time of projects but a time that can never be anticipated. When Bataille writes that "intimacy is violence," we should perhaps understand this in terms of the fragilities of inter-corporeality as much as the exposure by the present to a future that is to come, without any possibility of anticipation.

Bataille emphasizes that duration belongs to the world of objects. Objects are spatial and temporal syntheses. It is important to remember that Merleau-Ponty explains the illusion of transcendence by taking his departure precisely from that synthetic nature of perception. As is well-known, for Merleau-Ponty an object that appears in its thickness is spatial as well as temporal, and is never given to my perception from all the points of view at once. ${ }^{10}$ That the gaze is always bound to a certain perspective implies that the object will always absolutely be partially closed. Our classic and ordinary fiction of an "object" owes its being to the attribution of the primacy of vision over all the other senses, and to the presupposition that there can be an all-encompassing gaze. In Merleau-Ponty's terms, this illusion rests on our forgetting the role played by the spatiality of the living body in vision. We may say that our tendency, in our imagination, to separate the gaze from the living body to which it belongs is one of the conditions of transcendence that can make even the world itself an object. "It is the ex-stase of perception which causes all perception to be perception of something." "When we conceive the world as a big object, we forget that we inhabit the earth with our fellow creatures.

Now, immanent violence is an attempt to overcome the separation between the I and the other that gave rise to subjects and objects. If, in the age of technology, one can talk about violence on a plane of immanence which does not bring about or reproduce transcendence by becoming internal to 


\section{ZEYNEP DIREK}

the subject, history, God, and so on, then such violence may attest to the experience of the living body through pain, or through an experience of remembering that heals. The violence that results in transcendence objectifies - the female body killed by snuff is set on the screen as the ultimate object in which life is destroyed. On the other hand, in the lived experience of immanent violence, the desire is to destroy the object that is the human body, the human body as an object. Bataille knows well that our civilization treats the female body as an object of a male gaze; however, erotic experience as a sovereign experience cannot have anything to do with objectification, except to overcome it. In so far as the erotic is a touching of lost intimacy, it is the dissolution of both object and subject.

\section{II}

What can we know about immanence? By what right can we talk about it? The heaven where God lets Adam live after He has created him might be thought of as a magical realm of immanence. The forbidden fruit represents knowledge and transcendence. As soon as Adam eats it he is ashamed of his own naked body. $\mathrm{He}$ is separated from immanence in the affect of shame lacked by the animals. The Bible recognizes Adam's and Eve's banishment from the Garden of Eden as the beginning of mortality. The story of original sin as a mythical narrative of our exit from animality represents knowledge of the passage from the realm of immanence to that of transcendence as forbidden to us. In a way, this knowledge is the apple that has always already been eaten, and so cannot be set in front of us and contemplated. In Theory of Religion, Bataille is concerned with just that passage as being unknowable, as that which is not knowledge and which is impossible for us to know. Yet he implies that there are experiences that enable us to swim back and touch this other, immemorable earthly existence. What is consciousness of immanence? 
According to Bataille, our relation to where we are coming from- - that is, to animal life--is very different from our relation to objects. The obscurity of animal life for the human gaze is unlike the impenetrability of objects (TR 293/ 19-20). The foreign land of animal immanence cannot assume the senses human consciousness attributes to things in so far as they are given to it. If things get their sense by virtue of an original synthesis that results from an effort to know, animal immanence is neither full of sense nor senseless, for both alternatives require transcendence. The production of knowledge rests on our capacity to create linguistic idealities that shape and reconstruct our experience and to universalize that experience by assuming that we can substitute any rational consciousness for our own and obtain the same relation of knowing to what is known. According to Bataille, with respect to the distance we have so far traversed, animal is "at the half way point" (TR 293/21). That is not only to say that we come from the same source as animals, but also to emphasize the fact that we have spent a long time together on the path of evolution. This is precisely why animal life offers us an enigma that is much more difficult to see through than that offered to us by things. It is impossible to describe with certainty what the animal gaze sees; as Bataille says, "it can only be described by the poetry which slips toward the unknowable" (TR 293/21). ${ }^{12}$ Poetry, according to Inner Experience, is the "sacrifice of words" that enables the poet to express the primitive, silent language of things, the cry of the animal, and the vision of the child. ${ }^{13}$ In contrast to writing that seeks to clarify the sense of our experience of being in the world, poetry would seem to be closer to immanence. Poetry points to the "blurred consciousness" of "being at the half way point" where signification becomes expression of the immanent communication of all beings. Bataille describes the consciousness of immanence as blurred, operating with images rather than concepts; but such a consciousness is for him the internal communication of all living beings. The fact that it is not objective and reflective reminds us of Merleau-Ponty's 
description of incarnated consciousness: "To be a consciousness, or rather to be an experience, is to hold inner communication with the world, the body and other people, to be with them instead of being beside them." 14

An animal's gaze opens for me depths that are already familiar to me. This elusive depth that attracts me is my own (TR 294/22). Bataille does not attempt to think of the encounter with the animal in terms of the operative intentionality of an incarnated consciousness, as MerleauPonty would put it. Nor does he make expression depend on our capacity for cognitive representation. Our experience with animals reveals that we share a significant world with them. One of the reasons this sharing remains unthought in philosophy is our privileging of cognitive consciousness as mediating all intentionality. We fail to think through our own "elusive depth" opened by and in the animal gaze because, it might be suggested, we fear blurring the species distinction between human animals and non-human animals. A blurring of this barrier would put our cannibalistic civilization into question, and indeed, the violent exploitation of animal bodies may be the fundamental source of human transcendence. Why would human cannibalism be transcendent violence and not immanent violence? Bataille knows that the treatment of animals as if they were objects begins with the process of eating animals. ${ }^{15}$ In the present stage of modern capitalism, even the cutting of meat into pieces is not left to men. Technology veils the truth that the meat sold in the market was once part of an animal body. We manage to ignore the total uncanniness of the situation in which we find ourselves when we open the package of the chicken meat sold in the market and see that it involves four right and two left legs! There is no language that could bridge the discontinuity between the killing of the living animal, its fragmented corpse, and the meat on my table. On the contrary, the technological recreation of the language of cuisine makes all association between the dead animal and its meat impossible. 
Bataille emphasizes the fact that wild and domesticated animals are never "objects" for us. We think they are "closed" to us because we do not see any capacity for transcendence in them. We believe that we are the only beings that have transcended immanence and we are incapable of conceiving a potential for transcendence in any other nonhuman animal species. Transcendence must have always already been actualized wherever its conditions are present; it is not a process of growth (TR 295/23-24). Conceiving animals in terms of a lack of transcendence serves to burn the bridges between species by representing the distance between us as one that it is impossible to overcome, and to ignore that we have an emotional and corporeal communication with them. Instead of dwelling on the metaphysics of "the lack of transcendence" in animals, Bataille seems to invite us to revalue our immanent connection with them.

\section{III}

Having established the difference between immanent and transcendent violence, we can better understand why Bataille does not condemn all violence in ethical terms. If my reading is correct, he shows the subordinating function of transcendent violence and associates immanent violence with sovereignty. His account of violence is ontological as much as historical. Bataille's articulation of the various displacements of the borders between the profane world and sacred immanence in different historical worlds can be read in terms of an economical play between immanent violence and transcendent violence. We are not going to rehearse here the difficult movement that takes us to the disenchantment of the modern world characterized by pragmatism, scientism, and man's self-forgetfulness. Following Theory of Religion, I am going to focus on the phenomenon of sacrifice in the 
ancient pagan world in order to shed light on the question of why the economical play between the sacred and the profane has to be thought of in terms of violence.

The use of instruments plays a central role in the passage from immanence to transcendence. In accounting for the birth of the pagan world, Bataille makes clear that this passage can never leave immanence completely behind. Thus, we need to think discontinuity by partially reinstituting continuity. Because the subject of the pagan world is still very close to immanence, the object too is something to which mythical powers are attributed. The exchange between subject and object constitutes a universe of mythical transfers mediated by the "instrument." In other words, the pagan world consists of a "paradox" resulting from a transfer of the creative powers of the subject, by means of instruments, to the things that these instruments touch, manipulate, and produce. Hence, the pagan mind sees the world itself, including plants and animals, as inhabited by gods and spirits. Bataille gives us a dialectical account of the genesis of the "clarity" of the profane world, in which animals are completely subjected to utility, by starting from that paradox. The decisive moment in this development is the making of a distinction between body and spirit, which is made possible from within the ambiguous experience of the human corpse. ${ }^{16}$ The experience of the human corpse is both an affirmation of the human spirit and the final step in the reduction of the living animal-and of the living human body-to the status of a thing. When the animal becomes a useful or useless thing, it loses its status of being a fellow creature in man's eyes. Man, who still perceives the animality within himself, sees the animal as a "residue." This modification of the sense of man's experience of animals is associated with a modification in the sense of the experience of the world. Man experiences the world with a sentiment of discontentment, deprivation, and falling. His enslavement and appropriation of living creatures brings about his further alienation from nature, in which he forgets that he too belongs 


\section{BATAILLE ON VIOLENCE}

to it (TR 305/41). As nature becomes man's property, he loses the feeling of his immanent continuity with it. In negating nature, he negates himself (TR 305/41). The necessity to which the phenomenon of sacrifice corresponds appears at this very moment. Sacrifice is the act of taking the plant and the animal out of the world of utility in order to return them to immanence. Hence man affirms his original belonging to natural immanence by a negation of negation.

The reciprocal economy of the profane world of transcendence follows a logic of calculation in which the distinction between "useful" and "useless" beings appears to be drawn by means of a narrow conception of human interests. Sacrifice is an act of immanent violence that negates the restricted economy on which instrumental reason depends. It provides for an exit from the economy held in place by transcendent violence. By taking a potentially useful being in order to destroy the object in it, sacrifice aims at a temporary suspension of man's worries about production and accumulation. The general economy of expenditure without return to which the sacrifice aspires within the limits set by the profane world affirms man's original belonging to the sacred life of infinite generosity in which boundaries between Gods, humans, animals, and other existing beings are fluid.

As sacrifice negates the objective reality of the creature sacrificed, the sacrificing individual passes into a dreamy consciousness, one to be contrasted with the clarity of the objectifying consciousness. The sacrificing individual experiences his participation in the realm of immanence with anxiety or anguish (TR 312/51). The anxiety in question should also be a consequence of identification with the victim who is returned to immanence. In that blurred consciousness of anxiety, the community (of individuals) forgets that sacrifice is an attempt to make up for the injustice of reification, something humanity has been doing to nature, to animals, and to its own human animality. Thus the sacred that we reclaim in sacrifice is nothing other than our own incarnated co-existence with other living beings, i.e., our animality. 


\section{ZEYNEP DIREK}

The clarity of the world of work is achieved by a movement of transcendence. However, transcendence would always be haunted by what it has surpassed. What the world of utility projects into the realm of the sacred is in fact nothing but our own internal, intimate connectedness, which is never simply left behind. The profane world is not in fact threatened from without by the sacred; the threat comes from the repression of violence inherent to the excess of communicative life and the subordination of life energy to utility. Pagan consciousness is in a double bind. On the one hand, the clarity of the human world is produced by the transcendent violence exerted on our own immanence, that is, on our own animal and divine existence. On the other hand, the sacred-our own transfigured violent intimacy-is a continual threat to the profane. The latter, in its effort to preserve its own boundaries, looks for a way to make up for the violence it has been exerting on natural life. In fact, this is nothing similar to a symbolic compensation. The profane world has to find an outlet for the excess of immanent violence, which has the potential to explode in society as interior violence.

René Girard, in Violence and the Sacred, talks about societies that exterminate themselves through the unleashing of reciprocal violence when they cannot find a scapegoat to sacrifice. Sacrifice "is an instrument of prevention in the struggle against violence." ${ }^{17}$ Both immanent and transcendent violence can be reciprocal. Tying Bataille and Girard together, we can say that when the immanent violence that finds no other outlet explodes within a society in the form of "interior violence," it can easily take the character of reciprocal violence. Such violence does not aim at the establishment of structures and systems of production for growth and development but at death and destruction. As Girard puts it, the surrogate victim of the sacrifice is a pharmakos for the possibility of reciprocal violence that, once unleashed, may result in the self-destruction of the life of the community. ${ }^{18}$ In Bataille transcendent violence establishes differences that cannot be accounted for 


\section{BATAILLE ON VIOLENCE}

merely in terms of quantitative differences. Girard emphasizes that primitive mind fears the collapse of the differences on which society rests and perceives it as violence. ${ }^{19}$ According to Bataille, immanent violence eliminates the differences, dissolves the individuals, and returns them to indistinction. This is obviously a return to the natural condition. Girard and Bataille agree in their reflections on the social function of sacrifice against the unleashing of immanent violence, which destroys all the distinctions that transcendent violence had previously set and held in place. Nevertheless, Girard's analysis lacks Bataille's positive emphasis that with the disappearing of such distinctions, the boundaries of the social are transgressed toward a more original belonging together. We fear but also desire immanent life. It is the bearer of ultimate value and we touch it when the ordinary course of things is interrupted by experiences in which immanent violence makes itself felt, such as the carnal proximity of the other in the erotic relationship and the experience of another's death.

An ontological account of violence has to precede any discussion of the possibility of ethics and politics that takes Bataille's philosophical thought seriously. And the first conclusion here would be that any thinking of ethics in terms of a pacific relation to the other should take into account the fact that there is no intimacy which is not violence. One virtue of Bataille's thought for us today is its capacity to provide a philosophical ground for this--not only in terms of the power struggles of the world but also in terms of our incarnated coexistence.

Galatasaray University

\section{Notes}

${ }^{1}$ Georges Bataille, "Théorie de la religion," in Oeuvres Complètes, vol. 7 (Paris: Gallimard, 1976). English translation: Georges Bataille, Theory of Religion, trans. Robert Hurley (New York: Zone Books, 1989). Hereafter 


\section{ZEYNEP DIREK}

"TR." For ease of consultation, page references refer first to the French edition, then the English translation. All translations, however, are mine.

${ }^{2}$ Georges Bataille, The Accursed Share, vol. 1, trans. Robert Hurley (New York: Zone Books, 1988), p. 182; Georges Bataille, La Part maudite, in Oeuvres Complètes, vol. 7 (Paris: Gallimard, 1976), 171.

${ }^{3}$ Maurice Merleau-Ponty, Phenomenology of Perception, trans. Colin Smith (London and New York: Routledge \& Kegan Paul, 1962). A revised edition of this translation was published in 2002 , with new pagination. Subsequent page references refer first to the 1962 edition, then the 2002 edition.

${ }^{4}$ Merleau-Ponty, Phenomenology of Perception, xv/xvii.

${ }^{5}$ Merleau-Ponty, Phenomenology of Perception, xviii/xx.

${ }^{6}$ The French text reads : "Le lion n'est pas le roi des animaux: il n'est dans le mouvements des eaux qu'une vague plus haute renversant les autres plus faibles. Qu'un animal en mange un autre ne modifie guère une situation fondamentale: tout animal est dans le monde comme de l'eau à l'intérieure de l'eau." (TR 292).

${ }^{7}$ For Bataille, loss of sovereignty and fragmentation are related: they both have to do with the submission of our being to actions with definite ends. See Georges Bataille, SurNietzsche, in Oeuvres Complètes, vol. 6 (Paris : Gallimard, 1973). 17-18.

${ }^{8}$ Fight Club (1999) (Germany, USA), directed by David Fincher, based on a novel by Chuck Palahniuk, screenplay by Jim Uhls.

${ }^{9}$ The French text reads: "Rien n'est donné pour l'animal à longueur de temps. C'est dans la mesure où nous sommes bumains que l'objet existe dans le temps où sa durée est saisissable. L'animal mangé par un autre est donné au contraire en deçà de la durée, il est consommé, il est detruit, ce n'est qu'une disparition dans un monde où rien n'est posé en dehors du temps actuel" (TR 292).

${ }^{10}$ See "Experience and Objective Thought: The Problem of the Body," in Merleau-Ponty, Phenomenology of Perception, 67-72/77-83.

${ }^{11}$ Merleau-Ponty, Phenomenology of Perception, 70/81.

12 'The French text reads : "Ou plutôt, la manière correcte d'en parler ne peut être ouvertement que poétique, en ce que la poésie ne décrit rien qui ne glisse à l'inconnaissable" (TR 293)

${ }^{13}$ Georges Bataille, L'Expérience Intérieure, in Oeuvres Complètes, vol. 5 (Paris: Gallimard, 1973), p. 158.

${ }^{14}$ Merleau-Ponty, Phenomenology of Perception, 96/111.

${ }^{15}$ Bataille writes: "Dans la mesure où je puis voir aussi dans l'animal une chose (si je le mange - à ma manière, ce n'est pas celle d'un autre animal - ou si je l'asservis ou le traite en objet de science), son absurdité n'est pas moins courte (si l'on veut moins proche) que celle des pierres ou de l'air, mais il n'est pas toujours, et jamais il n'est 


\section{BATAILLE ON VIOLENCE}

tout à fait, réductible à cette sorte de réalité inférieure que nous attribuons aux choses." ["Insofar as I can also see the animal as a thing (if I eat it-in my own way, which is not that of another animal-or if I enslave it or treat it as an object of science), its absurdity is just as direct (if one prefers, just as near) as that of stones or air, but it is not always, and never entirely, reducible to that kind of inferior reality which we attribute to things."] (TR 294/2223). And a few pages later, he says: "L'homme ne mange rien avant d'en avoir fait un objet. Au moins dans les conditions ordinaires, l'homme est un animal qui ne participe pas à ce qu'il mange. Mais tuer l'animal et le modifier à son gré n'est pas seulement changer en chose ce qui ne l'était sans doute dès l'abord, c'est définir à l'avance l'animal vivant comme une chose. De ce que je tue, que je découpe, que je cuis, j'affirme implicitement que cela n'a jamais été qu'une chose." ["Man does not eat anything before he has made an object of it. At least in ordinary circumstances, man is an animal that does not participate in what he eats. But to kill the animal and alter it as one pleases is not merely to change into a thing that which doubtless was not a thing from the start; it is to define the animal in advance as a thing. Concerning that which I kill, which I cut up, which I cook, I implicitly affirm that that has never been anything but a thing."] (TR 304/39).

${ }^{16}$ Bataille writes : "Et l'esprit est si bien lié au corps-chose que celui-ci ne cesse jamais d'être hanté, n'est jamais chose qu'à la limite, au point que, si la mort le réduit à l'état de chose, l'esprit est plus présent que jamais: le corps qui l'a trabi le révèle davantage qu'au temps où il le servait. En un sens le cadavre est la plus parfaite affirmation de l'esprit." (TR p.305) ["The spirit is so closely linked to the body as a thing that the body never ceases to be haunted, is never a thing except virtually, so much so that if death reduces it to the condition of a thing, the spirit is more present than ever: the body that has betrayed it reveals it more clearly than when it served it. In a sense, the corpse is the most perfect affirmation of the spirit.'] (TR 305/40). Bataille emphasizes that man's attitude toward the body involves a deep complexity. On the one hand, the body is man's misery, the side which makes of him an animal, an object. On the other hand, it is sublimated as the bearer of the spirit. The spirit is so tightly connected to the body that because of its presence the body can only be "a thing at the limit." However, the spirit's presence in the body is never as apparent as when death makes the body a thing, a corpse. The corpse is the absence of the spirit yet it indicates and reveals the spirit. In this sense, "the corpse is the most perfect affirmation of the spirit."

${ }^{17}$ Rene Girard, Violence and the Sacred, trans. Patrick Gregory (London: The Athlone Press, 1988), 17.

${ }^{18}$ Girard, Violence and the Sacred, 54 and 95.

${ }^{19}$ Girard, Violence and the Sacred, 56. 